\title{
LABOR LAW: EVIDENCE OF BARGAINING HISTORY EXCLUDED IN DETERMINING ARBITRABILITY OF A SUBCONTRACTING GRIEVANCE
}

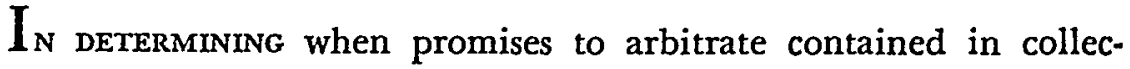
tive bargaining agreements are enforceable under section 301 (a) of the Taft-Hartley Act, ${ }^{1}$ the United States Supreme Court has imposed the burden of proof on parties who seek to avoid submitting grievances to arbitration. ${ }^{2}$ Those parties have often sought to discharge that burden by presenting extrinsic evidence of bargaining history manifesting an intention to exclude particular issues or disputes from arbitration. ${ }^{3}$ In International Union of Elec. Workers v. General Elec. Co., ${ }^{4}$ the Second Circuit Court of Appeals held such bargaining history evidence to be an improper subject for judicial consideration in determining arbitrability.

The union in General Electric sought to compel arbitration of a subcontracting grievance ${ }^{5}$ arising from the company's hiring of an independent contractor. General Electric asserted that the grievance was nonarbitrable since bargaining history clearly indicated that the parties intended to exclude subcontracting grievances from arbitration. ${ }^{\circledR}$ Although the history disclosed several

\footnotetext{
× Labor Management Relations Act $\S 301$ (a), 61 Stat. 156 (1947), 29 U.S.C. $\$ 185$ (a) (1958). See generally Hays, The Supreme Court and Labor Law October Term, 1959, 60 Colum. L. Rev. 901 (1960); Meltzer, The Supreme Court, Arbitrability and Collective Bargaining, 28 U. CHI. L. Rev. 464 (1961).

¿ See, e.g., United Steelworkers v. Warrior \& Gulf Nav. Co., 363 U.S. 574, 585 (1960); Panel Discussion, The Arbitration of Labor Disputes, 48 CHicaco B. REcond 282, 292 (1962); Snyder, What has the Supreme Court Done to Arbitration? 12 LAB. L.J. 93 (1961).

: See, e.g., Local 12298, UMW v. Bridgeport Gas Co., 328 F.2d 381 (2d Cir. 1964); Pacific Northwest Bell Tel. Co. v. Communications Workers, 310 F.2d 244 (9th Cir. 1962); Local 725, Int'l Union of Operating Eng'rs v. Standard Oil Co., 186 F. Supp. 895 (D.N.D. 1960).

6 332 F.2d 485 (2d Cir.), cert. denied, 379 U.S. 928 (1964), affirming 221 F. Supp. 6 (D. Conn. 1963). The case had been removed from the Connecticut Superior Court, to which it had been remanded by 148 Conn. 693, 174 A.2d 298 (1961), reversing 21 Conn. Supp. 175, 149 A.2d 910 (Super. Ct. 1959).

The union contended that the company's action violated provisions of its collective bargaining agreement, specifically those provisions for: (1) union recognition as exclusive bargaining representative; (2) job description; (3) seniority. $332 \mathrm{~F} .2 \mathrm{~d}$ at 487.

'Brief for Appellant, p. 36. The arbitration provision stated that "any grievance which remains unsettled after having been fully processed pursuant to the (grievance procedure) ... and which involves ... the interpretation or application of a provision of this agreement ... shall be submitted to arbitration." 332 F.2d at 488 .
} 
unsuccessful union attempts to insert contractual limitations on subcontracting in their collective bargaining agreements, the court of appeals ordered the company to arbitrate. It reasoned that an issue may not be excluded from arbitration unless an unambiguous exclusion clause or some other term of the agreement manifests beyond a doubt the intention of the parties that the particular matter was not to be arbitrable. In the absence of such a clause, the use of bargaining history to deny arbitration would be an improper encroachment upon the jurisdiction of the arbitrator. ${ }^{7}$

The role played by extrinsic evidence in the interpretation of arbitration provisions has recently undergone a significant change, ${ }^{8}$ precipitated by the 1957 decision of Textile Workers $v$. Lincoln Mills. ${ }^{9}$ In rejecting the former practice of applying traditional contract law to labor agreements, ${ }^{10}$ the Supreme Court there called for the evolution of a federal common law. ${ }^{11}$ regarding the adjudication of labor-management contracts. In 1960, the Court decided its famous trilogy of Steelworkers cases, ${ }^{12}$ the most important of which was United Steelworkers v. Warrior \& Gulf Nav. Co. ${ }^{13}$ There a con-

Two otber defenses, one based on a related NLRB action and the other asserting election of remedies by a union strike, were decided in favor of the union. Id. at 487 .

TId. at 488.

'See Bunn, Lincoln Mills and the Jurisdiction to Enforce Collective Bargaining Agreements, 43 VA. L. REv. 1247 (1957); Kramer, In the Wake of Lincoln Mills, 9 LAB. L.J. 835 (1958); Snyder, supra note 2; Comment, 34 So. CAL. L. REv. 63 (1960); 12 Syracuse L. Rev. 332 (1960).

- 353 U.S. 448 (1957).

${ }^{10} \mathrm{Id}$. at 456. For a detailed list of cases prior to Lincoln Mills, see Celanese Corp., 39 Lab. Arb. 925, 980 n.I (1959).

12 "We conclude that the substantive law to apply in suits under $\$ 801$ (a) is federal law, which the courts must fashion from the policy of our national labor laws." 353 U.S. at 456. See Banco Nacional de Cuba v. Sabbitino, 376 U.S. 398, 421 (1964).

${ }^{22}$ United Steelworkers v. American Mfg. Co., 363 U.S. 564 (1960); United Steelworkers v. Warrior \& Gulf Nav. Co., 363 U.S. 574 (1960); United Steelworkers v. Enterprise Wheel \& Car Corp., 363 U.S. 593 (1960). For detailed treatment of these decisions, see Hays, supra note I; Mayer, Labor Relations 1961: The Steelworkers Cases Re-examined, 13 LAB. L.J. 213 (1962); Meltzer, supra note 1; Wallen, Recent Supreme Court Decisions on Arbitration: An Arbitrator's View, $63 \mathrm{~W}$. VA. L. REv. 295 (1961); 46 CoRnell L.Q. 336 (1961); 49 GEo. L.J. 373 (1960); 59 MiCh. L. Rev. 454 (1961); 13 StaN. L. REV. 635 (1961).

${ }^{13} 363$ U.S. 574 (1960). In Warrior, the grievance before the court arose when defendant company discharged some of its employees, partly because certain maintenance work was contracted out to other companies. Many of the workers were rehired by the independent contractors at lower wages. Warrior and General Electric, it should be noted, are factually different in that the work subcontracted by Warrior \&. Gulf was work previously done by its employees, while the work subcontracted by General Electric was not normally performed by company workers. Chief Judge Lumbard, in his dissenting opinion in General Electric, indicates that in fact the 
tract provision broadly excluded "functions of management" from arbitration. The Court held a subcontracting grievance could not be included within the scope of such a broad provision and therefore was arbitrable. The decision stated that the fundamental policy of the labor law, promoting stability in labor relations by limiting judicial interference with the arbitral process in industrial self-government, would be thereby effectuated.14

The result of the Steelworkers decisions was to restrict severely the scope of questions open to judicial consideration in the area of labor-management arbitration..$^{15}$ The Court held that a decision on the merits in arbitration cases is within the province of the arbitrator, ${ }^{16}$ whereas the judicial function is limited to questions of arbitrability. In deciding whether an issue is arbitrable, Warrior created what amounts to a presumption of arbitrability, rebuttable only by an express clause of exclusion or by "forceful evidence of a purpose to exclude the claim from arbitration."17 This change in judicial emphasis from opposing to promoting arbitration in labor cases has obviated the necessity for claimants to rely upon bargaining history to secure arbitration, and increased the use of such evi-

company had wanted the subcontractor to use some of General Electric's employees, but because of the inter-union rivalry of the UE and the IUE, the subcontractor felt that the use of them would be impracticable. 332 F.2d at 494 .

14 363 U.S. at 582 . The arbitrator was viewed as more qualified than the courts to devine the true nature of the grievance and formulate a solution to the dispute. This was consonant with theories which called for a more limited role for court decisions in labor arbitration. See Cox, Reflections upon Labor Arbitration, 72 HARv. L. REv. 1482, 1509 (1959); Cox, Current Problems in the Law of Grievance Arbitration, 30 Rocky MT. L. REv. 247, 262-65 (1958); Shulman, Reason, Contract, and Law in Labor Relations, 68 HARv. L. REv. 999, 1024 (1955).

${ }^{15}$ An extensive list of district and appellate opinions since the Steelworkers de. cisions, indicating that most of the courts have permitted or required arhitration to proceed without judicial intervention and have upheld awards despite challenges going to the jurisdiction of the arbitrator, may be found in Smith, The Question of "Arbitrability"-The Roles of the Arbitrator, the Court, and the Parties, 16 Sw. L.J. 1 , 14 \& $n .27$ (1962). For arbitration decisions arising from court decisions ordering arbitration, see Fleming, Arbitrators and Arbitrability, 1963 WAsH. U.L.Q. 200.

18 "The courts ... have no business weighing the merits of the grievance, considering whether there is equity in a particular claim, or determining whether there is particular language in the written instrument which will support the claim. The agreement is to submit all grievances to arbitration, not merely those which the court will deem meritorious." United Steelworkers v. American Mfg. Co., 363 U.S. $564,568(1960)$.

17 "In the absence of any express provision excluding a particular grievance from arbitration, we think only the most forceful evidence of a purpose to exclude the claim from arbitration can prevail particularly where, as here, the exclusion clause is vague and the arbitration clause quite broad." 363 U.S. at 584-85; see authorities cited note 2 supra. 
dence by defendants in order to rebut the presumption of arbitrability.

Bargaining history has subsequently been considered in three basic contexts as a defense against claims to the right of arbitration: (1) to indicate the scope of a broad exclusion clause; ${ }^{18}$ (2) to demonstrate the intended extent of an arbitration clause; ${ }^{10}$ and (3) as "forceful evidence" of an intention to exclude a particular issue from arbitration. ${ }^{20}$

Those decisions which have considered the scope of broad exclusion clauses have generally favored the party who seeks the arbitration. ${ }^{21}$ Most courts have held that a broad grant of arbitration cannot be limited by a broad clause of exclusion, ${ }^{22}$ hence the use

${ }^{18}$ See, e.g., Marble Prod. Co. v. Local 155, United Stone Workers, 335 F.2d 468 (5th Cir. 1964); Taft Broadcasting Co. v. International Bhd. of Elec. Workers, 298 F.2d 707 (5th Cir. 1962); International Ass'n of Machinists v. Hayes Corp., 296 F.2d 238 (5th Cir. 1961); RCA v. Association of Professional Eng'r Personnel, 291 F.2d 105 (3d Cir. 1961); International Tel. \& Tel. Corp. v. Local 400, Int'l Union of Elec. Workers, 290 F.2d 581 (3d Cir. 1961); NEPCO Local 95, Office Employees Int'l Union v. Nekoosa-Edwards Paper Co., 287 F.2d 452 (7th Cir. 1961); Local 1912, Int'1 Ass'n of Machinists v. United States Potash Co., 270 F.2d 496 (10th Cir. 1959); A. S. Abell Co. v. Baltimore Typographical Union No. 12, 230 F. Supp. 962 (D. Md. 1964); Freight Drivers Union 557 v. Anchor Motor Freight, Inc., 207 F. Supp. I (D. Md. 1962); Hammond Newspaper Guild v. Hammond Pub. Co., 43 CCH Lab. Cas. 25220 (N.D. Ind. 1961). But see Local 725 Int'l Union of Operating Eng'rs v. Standard Oil Co., 186 F. Supp. 895 (D.N.D. 1960), where the court interpreted a broad exclusion clause, providing that "proposals to add to or change this agreement shall not be arbitrable," by holding the union's subcontracting grievance nonarbitrable in light of the parties' bargaining history. For criticism of the case, see Gould, The Supreme Court and Labor Arbitration, 12 LAR. L.J. 331, 344-45 (1961); Smith, supra note 17, at 17. For cases indicating the specificity required in exclusion clauses, see Desert Coca Cola Bottling Co. v. Teamsters Union Local 14, 335 F.2d 198 (9th Cir. 1964); Communications Workers v. New York Tel. Co., 327 F.2d 94 (2d Cir. 1964).

${ }^{10}$ See, e.g., Independent Soapworkers v. Procter \& Gamble Mfg. Co., 314 F.2d 38 (9th Cir. 1963), cert. denied, 374 U.S. 807 (1963); Pacific Northwest Bell Tel. Co. v. Communications Workers, 310 F.2d 244 (9th Cir. 1962), aff'd on rehearing, 337 F.2d 455 (9th Cir. 1964).

${ }^{20}$ For decisions which favor denying admissibility, see, e.g., Local 12298, UMW v. Bridgeport Gas Co., 328 F.2d 381 (2d Cir. 1964); International Ass'n of Machinists Lodge 1652 v. International Aircraft Serv. Inc., 302 F.2d 808 (4th Cir. 1962); Association of Westinghouse Salaried Employees v. Westinghouse Elec. Co., 283 F.2d 93 (3d Cir. 1960); International Chem. Workers v. Jefferson Lake Sulphur Co., 197 F. Supp. 155 (S.D. Tex. 1961); O'Malley v. Wilshire Oil Co., 59 Cal. App. 2d 482, 381 P.2d 188, 30 Cal. Rptr. 453 (Sup. Ct. 1963). For decisions favoring admissibility, see, e.g., UAW v. Cardwell Mfg. Co., 304 F.2d 801 (10th Cir. 1962); NLRB v. Guif Atl. Warehouse Co., 291 F.2d 475 (5th Cir. 1961); Local 725 Int'l Union of Operating Eng'rs v. Standard Oil Co., 186 F. Supp. 895 (D.N.D. 1960); Maryland Tel. Union v. Chesapeake \& Potomac Tel. Co., 187 F. Supp. 101 (D. Md. 1960).

${ }^{21}$ See authorities cited note 8 supra.

$\approx$ There is good inferential authority for that result. In Warrior it was held that orders to arbitrate grievances should not be denied unless it could be said "with positive assurance that the arbitration clause is not susceptible of an interpretation 
of bargaining history to define the latter is inappropriate. When used to define the scope of the arbitration clause, however, courts have been more receptive to such evidence. A history of negotiations indicating unsuccessful attempts to include certain matters expressly within the arbitration clause has been held admissible since it goes to the "judicial issue and not to the merits."23

The most frequent use of bargaining history has been in the third context, where a party asserts that such history presents "forceful evidence" that the parties intended to exclude a subject from arbitration. ${ }^{24}$ The Second Circuit in General Electric reasoned that although this evidence might be useful to an arbitrator examining the merits of the grievance, it is of no use to a court making the determination of arbitrability. ${ }^{25}$ The court gathers support ${ }^{20}$ for this position from its own prior decision interpreting the Steelworkers opinions, ${ }^{27}$ from the parallel holdings of at least one other circuit, ${ }^{28}$

that covers the asserted dispute. Doubts should be resolved in favor of coverage." 363 U.S. at 582 . It would seem almost inconceivable that a broad exclusion clause could ever be sufficient to arouse the "positive assurance" required of a court to deny arbitration.

In General Electric the court summarily rejected the company's argument that the "wrap up" clause was an exclusion clause sufficient to remove subcontracting grievances from arbitration when account was taken of bargaining history. 332 F.2d at 489. But see Smith, supra note 15, at 30 .

${ }^{28}$ Independent Soapworkers v. Procter \& Gamble Mfg. Co., 314 F.2d 38 (9th Cir.), cert. denied, 374 U.S. 907 (1963); Pacific Northwest Bell Tel. Co. v. Communications Workers, 310 F.2d 244 (9th Cir. 1962), affd on rehearing, 337 F.2d 455 (9th Cir. 1964). The majority opinion in General Electric distinguished these cases by limiting them to considerations of bargaining history of the arbitration clause itself, and at the same time emphasized that it intimated "no opinion as to the view expressed in those cases that some types of bargaining history may bc used in resolving arbitrability." 332 F.2d at 490 n.6.

On analysis, it is doubtful whether there is any substantial distinction between the use of bargaining history in defining the scope of the exclusion clause, and its use in defining the scope of the arbitration clause. Since both clauses are determinants of the extent to which the partics have promised to arbitrate, evidence of bargaining history would seem either to go to the merits in both instances or in both instances to present justiciable issues.

24 See note 20 supra.

25 "[B]y the reasoning of the majority we are pretty close to the point of holding that every claim must be arbitrated because at the very least it involves the question whether by some process of reasoning the claim may involve tangentially some provision in the agreement." 332 F.2d at 494 (dissenting opinion). See also Local 12298 UMW v. Bridgeport Gas Co., 328 F.2d 381, 384 (2d Cir. 1964) (dissenting opinion).

$3332 \mathrm{~F} .2 \mathrm{~d}$ at 488.

${ }^{27}$ Procter \& Gamble Independent Union v. Procter and Gamble Mfg. Co., 298 F.2d 644 (2d Cir. 1962) (Medina, J.). "[E]very grievance is arbitrable, unless the provisions of the collective bargaining agreement concerning grievances and arbitration contain some clear and unambiguous clause of exclusion, or there is some other term of the agreement that indicates beyond peradventure of doubt that a grievance concerning 
and from the fact that although similar bargaining history was before the Supreme Court in Warrior, that history received no comment in the majority opinion. ${ }^{29}$

The Seventh Circuit, however, has taken a position opposed to the Second Circuit on the issue of using bargaining history as "forceful evidence" of an intention to exclude a grievance from arbitration. ${ }^{30}$ That case was similar to General Electric in that the company had rejected union demands for contractual limitations on the company's power to subcontract, and the union had later sought arbitration of subcontracting grievances. The Seventh Circuit denied arbitration. and held that bargaining history has "some significance and. may be properly considered."31

The basis for the position advanced by the Seventh Circuit has been articulated and adopted in a subsequent decision by the Ninth Circuit. ${ }^{32}$ There the court held that a grievance arising from a disciplinary suspension of employees was nonarbitrable in view of the parties' bargaining history ${ }^{33}$ The Ninth Circuit reasoned that a judicial evaluation of the parties' intention in the area of collective bargaining should not be limited to a consideration of the four corners of the bargaining agreement and its collateral writings. ${ }^{34}$ Although it felt such a rule of evidence "would indeed be a most workable rule of thumb for the courts in this difficult area"3s it

a particular matter is not intended to be covered by the grievance and arbitration procedure set forth in the agreement." Id. at 645-46. (Emphasis added.)

${ }^{2}$ Association of Westinghouse Salaried Employees v. Westinghouse Elec. Co., 283 F.2d 93 (3d Cir. 1960).

${ }^{20}$ It has been suggested, however, that the court in Warrior, had it wanted to bar the use of bargaining history, could have easily foreclosed the issue by specifically denying its admissibility. Maryland Tel. Union v. Chesapeake \& Potomac Tel. Co., 187 F. Supp. 101, 108-09 (D. Md. 1960). But see Meltzer, supra note 11, at 470.

Yet it is noteworthy that the bargaining history in Warrior indicated an intent to preclude arbitration; nevertheless, the Court did not consider this evidence in reaching a contrary result. United Steelworkers v. Warrior \& Gulf Nav. Co., 363 U.S. 574, 59091 (1960) (dissenting opinion).

${ }^{80}$ Independent Petroleum Workers v. American Oil Co., 324 F.2d 903 (7th Cir. 1963), cert. granted, 379 U.S. 130 (1964) (No. 971, 1963 Term; renumbered No. 55, 1964 Term).

${ }^{81}$ Id. at 907 .

${ }^{32}$ Communications Workers v. Pacific Northwest Bell Tel. Co., 397 F.2d 455 (1961) (9th Cir. 1964).

${ }^{83}$ This was the second time the case had appeared before the court. Sce $\$ 10$ F.2d 244 (9th $\mathrm{Cir}$. 1962). Its re-examination was occasioned by recent opinions on the issue in other circuits. Communications Workers v. Pacific Northwest Bell Tel. Co., supra note 32 .

"Id. at 459. But see note 27 supra.

st 337 F.2d at $458-59$. 
found itself unable to "square such a rule" with the nature of the judicial function asserted by the Supreme Court. So long as the courts are to determine whether grievances are arbitrable, ${ }^{36}$ in the Ninth Circuit's opinion, bargaining agreements must be read in the light of bargaining history.

The Ninth Circuit, therefore, has emphasized those aspects of the Warrior opinion which permit a court to consider "forceful evidence" of an intention to exclude an issue from arbitration. The Second Circuit, on the other hand, emphasized the Warrior admonition to avoid considering the merits of these controversies and to permit the arbitration where doubts exist. ${ }^{37}$ It may be argued that bargaining history is not "forceful evidence" because it does not explain why the parties omitted to mention the grievance in an exclusion clause. Nevertheless, the "doubt" found by the court in General Electric may have been dispelled if bargaining history was held admissible. Whether or not such evidence would constitute a decision on the "merits" is an open question, as the standard for distinguishing between the merits and determining arbitrability is at best vague. In large measure, this conflict among the circuits is the result of judicial attempts to reach a balance between two conflicting objectives: on the one hand, the preservation of the process of arbitration as a means of minimizing industrial strife and, on the other, the prevention of a party from seeking anew before an arbitrator what he has lost at the bargaining table. ${ }^{88}$

While support can be found in recent Supreme Court opinions ${ }^{39}$ for both positions taken by the circuits, it is difficult to reconcile the admissibility of bargaining history evidence with the philosophy of the Warrior decision. In Warrior, the court sought to promote labor peace by reducing judicial interference with the process of

${ }^{30}$ Ibid. Recent Supreme Court decisions have reaffirmed the earlier holding that the courts are the determiners of arbitrability. Atkinson v. Sinclair Ref. Co., 370 U.S. 238, 241 (1962); Drake Bakeries v. Bakery Workers, 370 U.S. 254, 256 (1962).

${ }^{37}$ See notes $16,17 \& 22$ supra. The Ninth Circuit's adherence to its former ruling maintains an equal division of the circuits on this issue. The Seventh, Ninth and Tenth Circuits stand in opposition to the Second, Third and Fifth Circuits. 33 U.S.L. WeEk 1055 (U.S. Oct. 20, 1964). Certiorari has been granted in Independent Petroleum Workers v. American Oil Co., 324 F.2d 903 (7th Cir. 1963), cert. granted, 379 U.S. 130 (1964) (No. 971, 1963 Term; renumbered No. 55, 1964 Term).

${ }^{38}$ See, e.g., 332 F.2d at 494 (dissenting opinion). See also Local 12298 UMW v. Bridgeport Gas Co., 328 F.2d 381, 384 (2d Cir. 1964) (dissenting opinion).

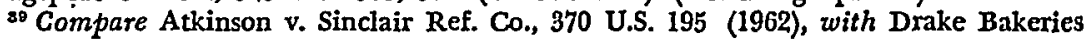
v. Bakery Workers, 370 U.S. 254, 263 (1962). 
self-government through arbitration.40 It is reasonable to assume that this policy contemplates the expeditious disposition of industrial disputes instead of time-consuming trials for the introduction of extrinsic evidence. In order for this policy to be effective, the judiciary should assume the responsibility of summarily dismissing contests over arbitrability interposed for purposes of delay. They can do this only by barring all considerations of extrinsic evidence, including bargaining history. ${ }^{41}$ The effect of this approach would render the Warrior "forceful evidence" test virtually inapplicable, and courts would actually determine arbitrability only in those instances of clear contractual restrictions on arbitration. In the final analysis, this limitation on the forceful evidence test is clearly outweighed by the disastrous effect which judicial delay would have on arbitration as a system of efficient industrial self-government. ${ }^{42}$

60 United Steelworkers v. Warrior \& Gulf Nav. Co., 363 U.S. 574, 582 (1960).

¿1 See authorities cited note 14 supra.

4 This does not necessarily mean, however, that the parties are denied all recourse to the courts. Professor Cox has suggested that "after the arbitrator has made his award there may be additional room for judicial scrutiny." Cox, supra note 14, at 265. While the Supreme Court has held in United Steelworkers v. Enterprise Wheel \&. Car Corp., 363 U.S. 593, 596 (1960) that the arbitrator's decision on the merits of an award is not reviewable, one decision subsequent to the Steelworkers opinions has reviewed such an award to determine whether it exceeded the "scope of the sub. mission." Textile Workers Local 1386 v. American Thread Co., 291 F.2d 894 (4th Cir. 1961). 